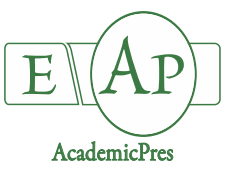

Pontes FM et al. (2021)

Notulae Botanicae Horti Agrobotanici Cluj-Napoca

Volume 49, Issue 2, Article number 12062

DOI: $10.15835 /$ nbha 49212062

Research Article

\title{
Physical and chemical properties, pectinases activity, and cell wall pectin of Acidulus, Momordica, Inodorus and Cantalupensis melons with different ripening degree at harvest
}

\author{
Felipe M. PONTES ${ }^{1}$, José D. A. SARMENTO ${ }^{1}$, Naama J. de A. MELO ${ }^{1}$, \\ Erika V. de MEDEIROS ${ }^{2 *}$, Patrícia L. D. MORAIS ${ }^{1}$, \\ Glauber H. de S. NUNES ${ }^{1}$
}

${ }^{1}$ University Federal Rural of Semi-Arrido, Agricultural Sciences center, Francisco Mota street, 59625-900, Mossoró, RN, Brazil; hamtaro_op@hotmail.com; darcioabrantes@yahoo.com.br; naama.melon@ufersa.edu.br;plmorais@hotmail.com;

glauber@ufersa.edu.br

${ }^{2}$ Federal University of Agreste of Pernambuco, Bom Pastor avenue, Garanhuns, Pernambuco, 55292-270, Brazil; evmbio@gmail.com

\section{Abstract}

The objective of the present study was to evaluate the physical and chemical changes, pectinases activity, and cell wall pectin in melon varieties Acidulus (access 16), Momordica (access 2), Inodorus (cv. 'Iracema') and Cantalupensis (cv. 'Olympic'), in the relation of ripening degree at harvest. Melon fruits were planted and evaluated with different ripening degree at harvest, from 15 to 35 days after anthesis (DAA). The fruits, arranged in a completely randomized design, had been evaluated on the harvest days to physical and chemical characteristics. We evaluate pectin methylesterase, polygalacturonase, beta-galactosidase, and pectin contents (water-soluble, chelate soluble, and sodium carbonate soluble). The ideal harvest for each melon was, 35 days after anthesis for cv 'Iracema', 30 days after anthesis for cv. 'Olympic', 30 days after anthesis for access 16, and 20 days after anthesis for access 2 . High pulp firmness of access 16 is associated with the high levels of sodium carbonate soluble pectin and low levels of polygalacturonase and beta-galactosidase activity. Momordica melon fruit cracking is related to the high levels of pectinases activity, as well as pectin degradation.

Keywords: beta-galactosidase; commercial; Cucumis melo; methylesterase; non-commercial melon; polygalacturonase

\section{Introduction}

The melon (Cucumis melo) is the fifth most important plant in terms of fruit production worldwide (Ortiz-Duarte et al., 2019) due to its high polymorphism degree. Such variability of melon fruits providing resistance to adverse environments and produces cultivars that satisfy a higher and diversified number of consumer markets (Aragao et al., 2013; Dai et al., 2019). The greatest consumer demand is for in natura fruit, mainly the commercial varieties, such as Inodorus and Cantalupensis.

Soluble solids and pulp firmness are commonly tested value to define the best degree of ripeness in the harvest of melon fruits and are the most important quality parameters for the industry and the consumer $(\mathrm{Li}$

Received: 01 Sep 2020. Received in revised form: 14 Apr 2021. Accepted: 27 Apr 2021. Published online: 29 Apr 2021.

From Volume 49, Issue 1, 2021, Notulae Botanicae Horti Agrobotanici Cluj-Napoca journal uses article numbers in place of the traditional method of continuous pagination through the volume. The journal will continue to appear quarterly, as before, with four annual numbers. 
et al., 2019). Soluble solids in melon are mostly composed of sugar, but varieties as Acidulus and Momordica have a distinct flavor, more citric, due to its high acidity and low sugar concentrations (Aragao et al., 2013). The firmness and texture element tend to reduce with ongoing maturation, due typically to cell wall degradation that occurs particularly by enzyme catalysis (Chen et al., 2015).

Cell walls, turgor pressure, and cellular tissue organization are essential to preserve mechanical strength, and rigidity, affecting the fruit sensory texture and firmness (Kozioł et al., 2017). In consequence, pulp softening affects the melon quality considerably. Therefore, studies of cell wall metabolism of commercial and non-commercial melon fruits can contribute to the development of postharvest technologies due to the phenotypical difference among evaluated materials.

Cell walls are the keys to preserve mechanical strength, and rigidity, affecting the fruit sensory texture and firmness. The constitution of the primary cell wall has three classes of polysaccharides: cellulose (15-40\%), hemicelluloses (20-30\%) and pectins (30-50\%). Pectin solubilization is the leading cause of firmness loss and influence on fruit quality. During fruit growth and ripening, protopectinase depolymerized protopectine (an insoluble form of pectin), forming soluble pectin's; besides, the cell-wall enzymes and proteins, as pectinases, changed the structure of cell wall polysaccharides (Chen et al., 2015).

Different enzymes controlled the structural modifications of fruit cell-wall pectins in relation to ripening degree. Pectin methylesterase (PME), polygalacturonase (PG), and beta-galactosidase (beta-gal) are the main pectinases in melons fruits. PME acts in series with the PG, esterifying the uronic acid backbone, making it a suitable substrate to be cleft by PG. The beta-gal catalyzes the hydrolysis of neutral sugars side chains, principally galactose ( $\mathrm{Li}$ et al., 2011).

There is an extensive literature elucidating physical and chemical changes, and cell wall pectin of commercial fruits in different ripening degree at harvest (Chisari et al., 2009; Vallone et al., 2013; Zhang et al., 2016). However, there are still gaps in elucidating these changes on melon fruits considered non-commercial and are essential for plant breeding studies. Future efforts for breeding melon quality are required because many of the characterized landraces and wild accessions have been underexploited (Esteras et al., 2020). Varieties with low importance on the traditional melon marketing, as Acidulus and Momordica, showed high potential for the genetic fruit improvement. India and other Asian countries appreciate these melons due to peculiar organoleptic characteristics (Sales et al., 2015). Studies showed that Acidulus have long shelf-life, compared to commercial melons, in the other hand Momordica is highly perishable, together with tissue cracking at the ripening (Manohar and Murthy, 2012).

Studies about the phenotype of unusual varieties are essential for breeding programs, and the contrast of the firmness among these varieties represent a valuable source for texture change. To verify this hypothesis, we investigated the physical and chemical changes, pectinases activity, and cell wall pectin in melon varieties Acidulus (access 16), Momordica (access 2), Inodorus (cv. 'Iracema') and Cantalupensis (cv. 'Olympic') with different ripening degree at harvest.

\section{Materials and Methods}

\section{Plant material and treatment condition}

Four melon varieties (Acidulous-access 16; Momordica-access 2; Inodorus-cv. 'Iracema'; and Cantalupensis-cv. 'Olympic'), were planted in the field in the Mossoró city - Rio Grande do Norte, Brazil $\left(5^{\circ} 12^{\prime} 25.9^{\prime \prime} \mathrm{S} 37^{\circ} 19^{\prime} 06.5^{\prime \prime} \mathrm{O}\right)$. The climate in the region is BSh (hot semi-arid climate), according to Köppen's classification and the soil is classified as red-yellow, eutrophic, abrupt and sand-free sandstone.

The seeds were planted on the day on the July 7 th 2015 , in polystyrene trays, and after seven days plants were placed to open field in two lines, for each material, of $30 \mathrm{~m}$ spaced $2.00 \times 0.3 \mathrm{~m}$. There were weekly weed control and plagues and disease chemical control when needed. Fertigation was performed until 60 days after 
transplanting, with $155 \mathrm{~kg} \mathrm{ha}^{-1}$ of urea, $148 \mathrm{~kg} \mathrm{ha}^{-1}$ of MAP, $85 \mathrm{~kg} \mathrm{ha}^{-1}$ of KCl, $56 \mathrm{~kg} \mathrm{ha}^{-1}$ of magnesium sulfate and $214 \mathrm{~kg} \mathrm{ha}^{-1}$ of sulfate potassium.

After blossom start, every morning the female flowers were tagged with colored wool when opened, a color per day. Fruits were collected in five states according to Table 1.

Table 1. Material, variety, opening of the first flower and ripening degree at harvest of melons

\begin{tabular}{|l|l|c|c|c|c|c|c|c|}
\hline \multirow{2}{*}{ Material } & \multirow{2}{*}{ Varieties } & \multirow{2}{*}{ Origin } & \multirow{2}{*}{$\begin{array}{c}\text { Flower opening } \\
(\mathrm{DAP})^{*}\end{array}$} & & \multicolumn{4}{|c|}{ Maturation stage $\left(\mathrm{DAA}^{* *}\right)$} \\
\cline { 5 - 9 } & & & E1 & E2 & E3 & E4 & E5 \\
\hline Access 16 & Acidulus & UFERSA & 35 & 15 & 20 & 25 & 30 & 35 \\
\hline Access 2 & Momordica & UFERSA & 39 & 15 & 20 & 25 & 30 & 33 \\
\hline 'Iracema' & Inodorus & Sakata & 40 & 15 & 20 & 25 & 30 & 35 \\
\hline 'Olympic' & Cantalupensis & Sakata & 37 & 15 & 20 & 25 & 30 & 33 \\
\hline
\end{tabular}

${ }^{*}$ DAP - Days after Planting

${ }^{* *}$ DAA - Days after anthesis

After harvested, fruits were immediately washed and sanitized to the evaluations. Upon arrival in the laboratory, all fruits were selected for uniform size, color, shape and free from visual defects. Fruits were randomly distributed into four groups each of five, and each group was divided into five replicates of five. We evaluate four varieties: 1. Access 16 (Acidullus), 2. Access 2 (Momordica), 3. 'Iracema' (Inodorus) e 4. 'Olympic' (Cantalupensis) in five ripening degree at harvest (E1, E2, E3, E4 and E5).

The Access 16 (Acidullus) is characterized by keeping firm until the end of ripening degree at harvest, but little flavor. Low acid-soluble solids ratio. Access 2 (Momordica) is characterized by cracking and opening at the end of maturation, it also has soft flavor. 'Iracema' (Inodorus) is commercial variety of the yellow group (non-climacteric). 'Olympic' (Cantalupensis) is commercial variety of the climatic group.

\section{Physical melon attributes}

Fruits were measured to: mass (g), using digital scale with two decimal places; longitudinal and transversal diameter $(\mathrm{mm})$, using a digital pachymeter; Pulp thickness and cavity (mm); Pulp thickness per cavity rate (PT/C); Rind and pulp color, using a digital colorimeter from Minolta, model "CR410", in CIELab color system; and fruit and pulp firmness $(\mathrm{N})$, using a texturometer from the brand Stable Micro Systems, model “TA.XTExpress/TA.XT2icon”, set up with pre-test speed of $1 \mathrm{~mm} / \mathrm{second}$, test speed of $5 \mathrm{~mm} / \mathrm{second}$, post-test speed of $10 \mathrm{~mm} / \mathrm{second}$, penetration deep of $10 \mathrm{~mm}$, penetration force of $0.0049 \mathrm{~N}$ and equipped with $\mathrm{P} / 5$ stainless cylindrical probe of $5 \mathrm{~mm}$ diameter, measuring from two opposite points in the fruit rind equator and central flesh part of the fruit cut longitudinally.

\section{Chemical melon attributes}

The fruits edible pulp was completely extracted using a stainless knife and processed in domestic blender. A pulp portion was used to measure the potential of hydrogen $(\mathrm{pH})$, using a digital potentiometer, with reading straight on the juice (AOAC, 2002); titratable acidity (mmol de $\mathrm{H}_{3} \mathrm{O}^{+*} 100 \mathrm{ml}^{-1}$ of juice); Soluble solids (\%), using a digital refractometer (AOAC, 2002) and vitamin C $\left(\mathrm{mg}^{*} 100 \mathrm{~g}^{-1}\right)$, by the DFI method (Strohecker and Henining, 1967). The remaining pulp was collected in three black plastic recipients, one for enzymatic assay, another for cell wall extraction, and the last one for determine the percentage of total soluble sugar, by the anthron method. The collected material was placed in freezer at $-18^{\circ} \mathrm{C}$, before the evaluations.

\section{Enzyme extraction and assay}

Pectin methylesterase (PME; EC 3.1.1.11) was extracted by homogenization of $5 \mathrm{~g}$ of pulp with a turax, for one minute, with $20 \mathrm{ml}$ of $\mathrm{NaCl} 0.2 \mathrm{~N}$ and filtered (Jen and Robinson, 1984). For poligalacturonase (PG; EC 3.2.1.1), $5 \mathrm{~g}$ of pulp were homogenized with sodium acetate buffer $0.1 \mathrm{M}, \mathrm{pH} 6,0$, containing $1 \%$ of Polyvinylpyrrolidone (PVP) and $0.5 \mathrm{M}$ of NaCl, with turax for 30 seconds, filtered with organza and the liquid 
fraction was centrifuged at $10000 \mathrm{RPM}$ for 30 minutes at $4{ }^{\circ} \mathrm{C}$, supernatant constituted the enzyme extract (Pressey and Avants, 1973). Beta-galactosidase (Beta-gal; EC 3.2.1.23) was extracted from $5 \mathrm{~g}$ of pulp homogenized for 30 seconds with $25 \mathrm{~mL} \mathrm{NaCl} 0,15 \mathrm{M}$ containing 1\% PVP, the solution was then centrifuged at $10000 \mathrm{RPM}$ for $20 \mathrm{~min}$ at $4{ }^{\circ} \mathrm{C}$, and the supernatant was collected as enzyme extract (Li et al., 2011).

The PME was measured by titling $\mathrm{NaOH} 0.1 \mathrm{~N}$ during 10 minutes in $30 \mathrm{~mL}$ of $1 \%$ citric pectin diluted in $0.2 \mathrm{~N} \mathrm{NaCl}$ with the enzyme extract, to maintain $\mathrm{pH}$ at 7 , enzyme activity was calculated using the amount of $\mathrm{NaOH}$ consumed. PG activity was determined by mixing $3 \mathrm{~mL}$ of the extract with $3 \mathrm{~mL}$ of $0,25 \%$ polygalacturonic acid diluted in sodium acetate buffer, $\mathrm{pH}$ 5(AR2), a blank was made with $3 \mathrm{~mL}$ water instead of extract (AR1). Both AR2 and AR1 were incubated under $30{ }^{\circ} \mathrm{C}$ for 3 hours, then the reaction was interrupted with water bath at $100^{\circ} \mathrm{C}$, for 5 minutes, and cooled in ice bath. The activity was the difference of reducing substances among AR2 and AR1 obtained by the Miller (1959) method. Beta-gal activity, was determined by incubating $0.5 \mathrm{~mL}$ of enzyme extract with $0.5 \mathrm{~mL}$ of synthetic p-nitrophenyl $\beta$ galactopyranoside $0.003 \mathrm{M}$ dissolved in Mcllwaine buffer, $\mathrm{pH}$ 4, for 15 minutes at $37^{\circ} \mathrm{C}$, after that, the reaction was interrupted with $1.5 \mathrm{~mL}$ of $0.1 \mathrm{M}$ sodium carbonate (color change to yellow), then photometry was performed at $400 \eta \mathrm{m}$. All activities were expressed in $\eta \mathrm{mol}^{*} \mathrm{~min}^{-1 *} \mathrm{~g}^{-1}$ of pulp weight.

\section{Cell wall extraction and fractionation}

Cell wall material was obtained by Chong et al. (2015), with slight modifications. Extraction was made by boiling $20 \mathrm{~g}$ of pulp in $200 \mathrm{~mL}$ of $80 \%$ ethanol for 20 minutes, the processes was repeated twice after filtration. The residue was incubated in $50 \mathrm{~mL}$ of dimethylsulfoxide (DMSO) $(9: 1 \mathrm{v} / \mathrm{v})$, at $4{ }^{\circ} \mathrm{C}$, overnight. Then, the residue was dipped in $200 \mathrm{~mL}$ of chloroform ethanol $(2: 1 \mathrm{v} / \mathrm{v})$, for 10 minutes, and after it was washed with acetone until total whitening. Once dried out, the residue was collected as cell wall material (CWM).

The fractionation extracts were obtained by agitating $0.1 \mathrm{~g}$ of CWM with $10 \mathrm{~mL}$ of distillated water for 4 hours at $25^{\circ} \mathrm{C}$, and then, centrifuged at $10000 \mathrm{RPM}$, for 10 minutes at $4{ }^{\circ} \mathrm{C}$, collecting the supernatant, the process was repeated with the residue twice, the three supernatants were mixed and stored as water soluble pectin (WSP). The chelate soluble pectin (CSP) extract, followed the same process with the same residue from WSP, but instead of water, the agitation was made with $10 \mathrm{~mL}$ of CDTA $50 \mathrm{mM}$, and for sodium carbonate soluble pectin (SSP) the extraction was performed with sodium carbonate $50 \mathrm{mM}$ containing $2 \mathrm{mM}$ of CDTA. The determination of pectin concentration was performed by carbazol method, using a galacturonic acid curve, absorbance at $530 \eta \mathrm{m}$, the concentration was expressed in $\mathrm{mg}^{*} 100 \mathrm{~g}^{-1}$.

\section{Statistical analysis}

The design was totally random, with five treatments and five replicates for each variety. The treatments consist of five times after anthesis, related on Table 1. It was used one fruit per parcel, totalizing 25 fruits per variety. It was performed ANOVA for polynomial regression using the software Sisvar 5.6, when no significance or no adjustment was found, there were present the mean.

\section{Results and Discussion}

\section{Physical and chemical properties}

The commercial and non-commercial of melons fruits showed a high variation of mass. The access 2 melons showed mass of fruit 2.41 times higher than access 16 melon (Table 2). Dos Santos et al. (2011) studied hybrids of yellow melon and obtained mass of fruit $1340 \mathrm{~g}$ (genotype CNPH 133) and $1640 \mathrm{~g}$ (genotype CNPH $136)$ that is higher than the mass of melon of commercial 'Iracema' $(1137 \mathrm{~g})$. According to Araújo Neto et al. (2003), consumers prefers fruits with mass less than $1800 \mathrm{~g}$, showing that all the melons evaluated in this study are within the preference standards. 
Table 2. Physical attributes of melons from varieties Acidulus (Access 16), Momordica (Access 2), Inodorus (cv. 'Iracema') and Cantalupensis (cv. 'Olympic')**

\begin{tabular}{|c|c|c|c|c|c|c|c|}
\hline Melon & Mass (g) & $\begin{array}{c}\text { Longitudinal } \\
\text { diameter } \\
(\mathrm{mm})\end{array}$ & $\begin{array}{c}\text { Transversal } \\
\text { diameter } \\
(\mathrm{mm})\end{array}$ & Shape index & $\begin{array}{c}\text { Pulp thickness } \\
(\mathrm{mm})\end{array}$ & $\begin{array}{c}\text { Cavity } \\
(\mathrm{mm})\end{array}$ & $\begin{array}{c}\text { PT/C } \\
\text { rate }\end{array}$ \\
\hline Access 16 & 563,00 & 162,41 & 78,10 & 2,09 & 19,20 & 41,08 & 0,46 \\
$\pm 271,78$ & $\pm 28,62$ & $\pm 14,30$ & $\pm 0,16$ & $\pm 5,08$ & $\pm 5,79$ & $\pm 0,09$ \\
\hline Access 2 & 1359,20 & 193,97 & 84,66 & 2,29 & 20,84 & 44,89 & 0,47 \\
& $\pm 565,01$ & $\pm 108,82$ & $\pm 46,37$ & $\pm 0,31$ & $\pm 11,48$ & $\pm 24,85$ & $\pm 0,09$ \\
\hline 'Iracema' & 1137,00 & 159,66 & 128,46 & 1,25 & 31,90 & 57,13 & 0,56 \\
& $\pm 347,69$ & $\pm 35,33$ & $\pm 33,12$ & $\pm 0,07$ & $\pm 5,05$ & $\pm 6,31$ & $\pm 0,08$ \\
\hline 'Olympic' & 965,20 & 138,88 & 138,83 & 1,00 & 35,49 & 51,67 & 0,69 \\
& $\pm 309,35$ & $\pm 39,99$ & $\pm 38,62$ & $\pm 0,05$ & $\pm 5,88$ & $\pm 5,60$ & $\pm 0,13$ \\
\hline
\end{tabular}

${ }^{*}$ Pulp thickness per cavity rate.

** Values expressed by means \pm standard derivation $(\mathrm{n}=25)$.

The melons of commercial and non-commercial showed similar longitudinal diameter (Table 2). However, the transversal diameter of commercial melon fruits was higher compared to non-commercial. For example, the 'Olympic' melon showed transversal diameter 1.78 times higher than Access 16. Queiroga (2008) studying the commercial cantaloupe melons, hybrids 'Torreon', found transversal diameter values around 100 to $125 \mathrm{~mm}$, lower than commercial 'Iracema' and 'Olympic' found in the present study.

Fruit format for both non-commercial accesses were cylindrical, with format index over 1.7 (Table 2), while the commercial 'Iracema' and 'Olympic' cultivars showed oblong $(1.10<\mathrm{IF} \leq 1.70)$, and spherical $(0,90<\mathrm{IF} \leq 1,10)$ respectively. Industries prefer fruits with FI close to 1 since values further than that affect the packing (Purquerio and Cecílio Filho, 2005), as found in 'Olympic' melons.

The commercial Olympic melon showed the pulp thickness and PT/C rate (1.85 and 1.5 times) higher than non-commercial access 16 (Table 2). According to Rizzo and Braz (2001) fruits with less pulp thickness shows bigger cavity. However, this relation was no observed in the present study due the commercial melon fruits showed higher pulp thickness and higher cavity compared to non-commercial melon fruits.

\section{Rind and pulp color}

Pulp luminosity of commercial 'Olympic' melon decrease with the days after anthesis. However, Access 16 and 'Iracema' melon showed a small increase over the days (Figure 1A). Rinds $\mathrm{a}^{*}$ and $\mathrm{b}^{*}$ of commercial and non-commercial melons increases with the days after anthesis (Figure 1B and 1C). According to Munira et al. (2013) the rind luminosity is associated with the maturation stage of fruits. This physical property is related to light retention of substances as chlorophyll. Therefore, as long as the rind chlorophyll levels decrease, light retention goes down due to degradation. Tadmor et al. (2010) studying the rind pigmentation of 'Dulce', 'Rochet' and 'Noy-Amid' melons, verified a reduction on chlorophyll concentrations, during maturation, for all fruits.

The rinds of all melon fruits studied showed an increase on $\mathrm{a}^{*}$ values, indicating a reduction on greening color (Figure 1 B). Non-commercial Access 16 and commercial cv. 'Olympic' showed higher values of a* (6.71, and 6.83 , respectively) on the last maturation day, which means theses fruits have some concentration of carotenoids, that express color from orange to red. Access 2 and cv. 'Iracema' had a* values close to zero, so less intensity of red color. The behavior of different types of melon can interfere with the increase or decrease in the concentration of carotenoids throughout ripening. For example, Tadmor et al. (2010) observed an increase of rind carotenoids during the maturation of 'Dulce' and 'TVT' melons; However, melons cv. 'Noy Amid' had a decrease at same conditions, interfering in the rind color formation, with a more intense color for 'Dulce' and 'TVT'. Here, the commercial cv. 'Olympic' showed more intense color at the last day of maturation. 

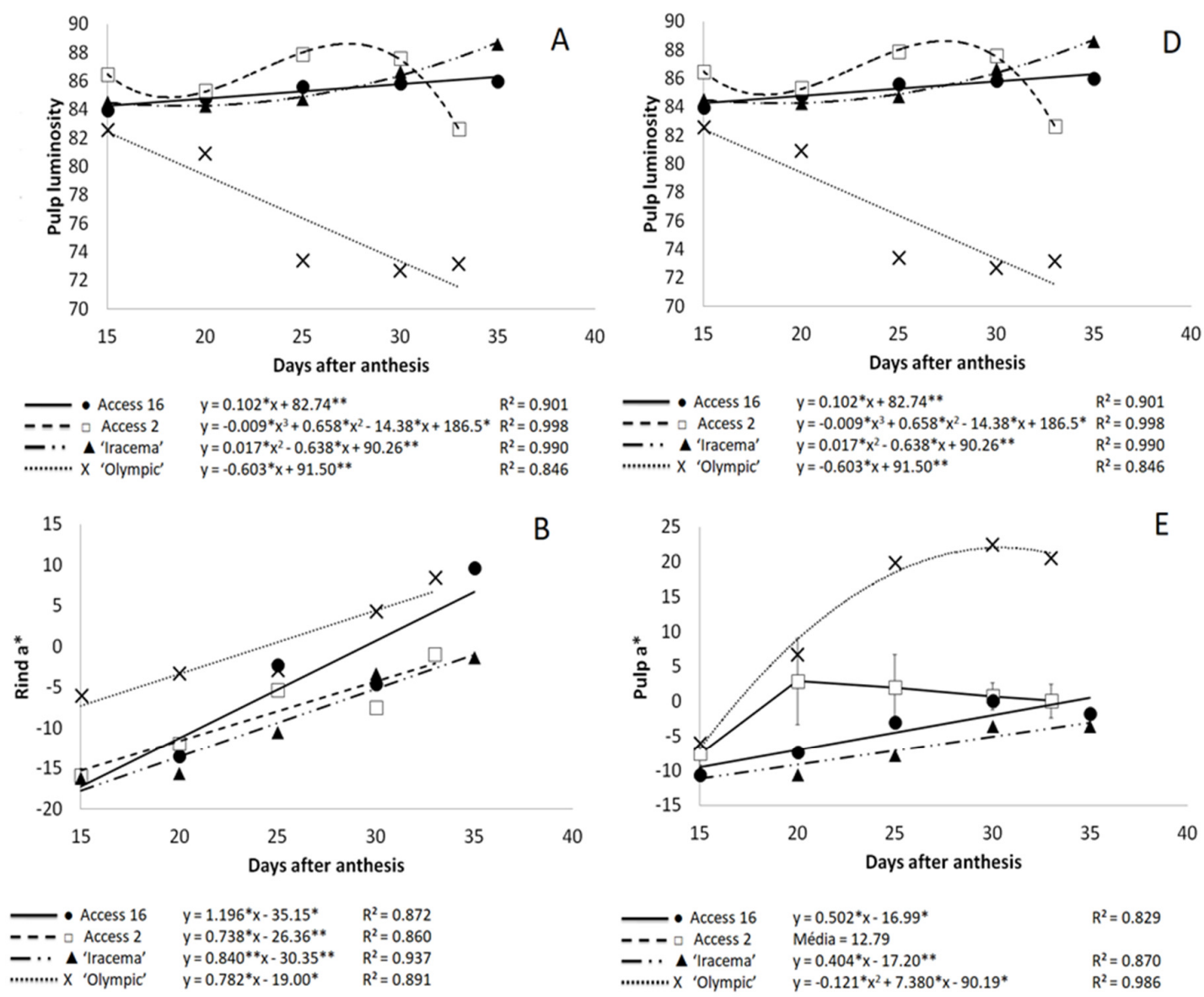

.......... X 'Olympic'

$y=0.404^{*} x-17.20^{* *}$

$R^{2}=0.870$

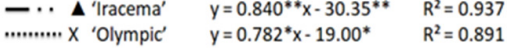
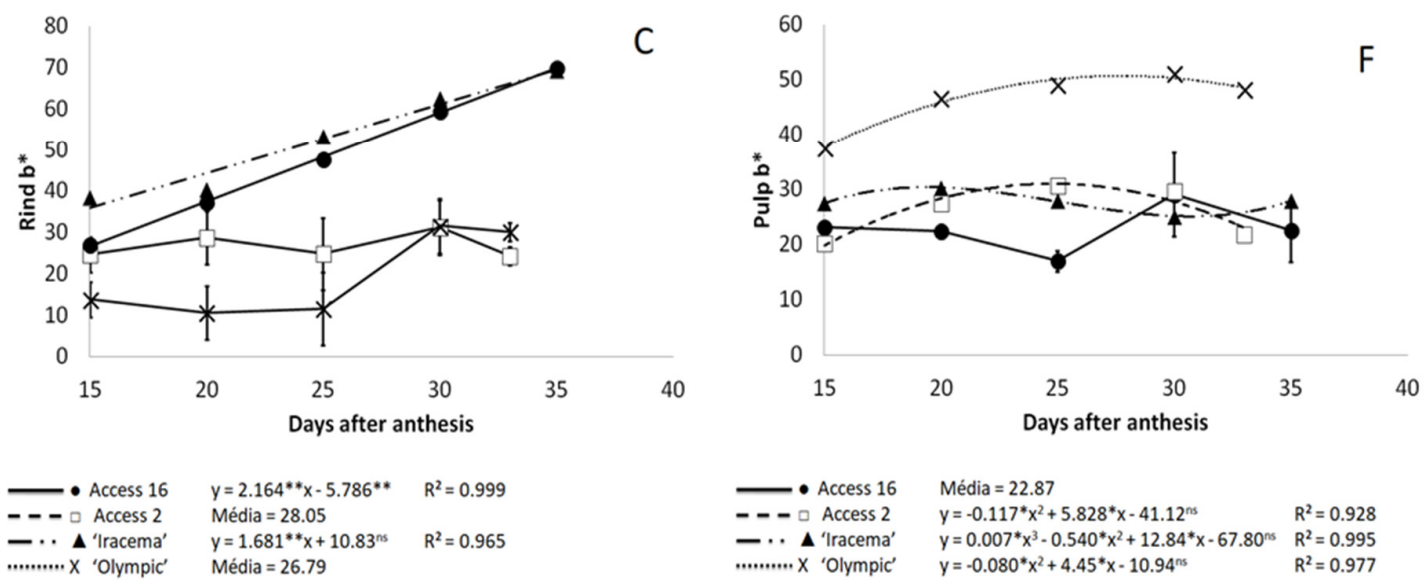

Figure 1. Rind and pulp color measured by CIEL*a* ${ }^{*}$ system, of Acidulus (Access 16), Momordica (Access 2), Inodorus (cv. 'Iracema') and Cantalupensis (cv. 'Olympic') melons with different ripening degree at harvest. ${ }^{*}$ significant at $5 \%$ probability, ${ }^{* *}$ significant at $1 \%$ probability, ns $=$ not significant 
The Access 2 melons showed no change of ring $b^{*}$ over the maturation period (with mean of 28.05; Figure $1 \mathrm{C}$ ), showing yellowish-green color fruits at the last ripening period evaluated. The more intense yellow color was observed in access 16 and 'Iracema', at the last day of ripening, expressed by rind b* values of 68.8, and 69.7, respectively. Tadmor et al. (2010) verified a considerable increment of naringenin chalcone flavonoid, during 'Noy amid' and 'Rochet' maturation, associating this substance concentration to the yellow rind intensification. Here, the access 16 and 'Iracema' coloration is propitiated by a high flavonoid concentration, present on the rind of both kinds of melons.

The evaluated melons showed different behaviors regarding pulp luminosity over the days of ripening. Access 16 and cv. 'Iracema' pulp color had an increase in luminosity, during the whole ripening (Figure $1 \mathrm{D}$ ). However, Access 2 showed a low decrease in the last days when it started to crack, possibly because of moisture loss, reducing light reflection. 'Olympic' had a high loss of brightness $(-13.16 \%)$, as it passed from greenishwhite to intense orange, during maturation.

The pulp $\mathrm{a}^{*}$ of all melon evaluated increased with the days after anthesis (Figure $1 \mathrm{E}$ ). There was a color intensity reduction on access 16 and 2 and cv. 'Iracema', due to pulp a* values that went close to zero, associated with low changes in $b^{*}$ (Figure $1 \mathrm{E}$ and $\mathrm{F}$ ). On the other hand, the values of $\mathrm{a}^{*}$ and $\mathrm{b}^{*}$ of 'Olympic' melons resulted in a chroma increment. Such color variation on cv. 'Olympic' is attributable to pulp orange intensification, not observed to the other melons, with a whitish color.

\section{Titratable acidity, $p H$, soluble solids content, soluble sugar content and vitamin $C$}

The ripening period increased the acidity level of non-commercial melons (access 16 and 2) that are characterized by the sour taste of Acidulus and Momordica varieties (Figure $2 \mathrm{~A}$ ), with a highlight to access 16, that on 29 days after anthesis showed a maximum point of $11.72 \mathrm{meq}^{*} 100^{-1}$. The change of acid over ripening is result of processes as synthesis, degradation, and transport that occurs in the plant ( $\mathrm{Li}$ et al., 2020). For example, acidity raise can be related to fruit low respiration rate (reducing the citric acid cycle), accumulating organic acids from phloem unloading. Zhang et al. (2016), studying the transcriptomic profile of 'Hami' melon, verified enzymes from citric acid cycle acting synergistically, accumulating citrate, and high levels of citrate in cells activated enzymes that degrade it, what explains the inflection point observed in access 16 and cultivar curves. Here, commercial melons ('Iracema' and 'Olympic') showed maximum acidity level at 20 and 25 days after anthesis and decreased until the last day of evaluation. The high acid content makes the fruit less palatable and reduces the fruit quality (Li et al., 2020).

Besides its narrow variation, the melons $\mathrm{pH}$ had an inverse behavior when compared to acidity (Figure $2 \mathrm{~B}$ ), which the lower $\mathrm{pH}$ values were observed on the last days in non-commercial melons (amounts close to 5), while the commercial melons showed $\mathrm{pH}$ over 6 at the last day evaluated. Most fruits have strong acidity, but, sweet melons, commonly, detain low acidity, when ripe, with $\mathrm{pH}$ around 6 . Nevertheless, there is a high genetic variation in this species, and some genotypes can accumulate high levels of organic acid in the fruit, characterizing a pH lower than 5 (Cohen et al., 2012).

Commercial and non-commercial melons increased soluble solids according to ripeness (over the days after anthesis), with different level of increases: access 16 of $27.60 \%$, access 2 of $73.70 \%$, 'Iracema' of $31.65 \%$ and 'Olympic' of 101.09\% (Figure 2 C). Tomaz et al. (2009) studied five yellow melon hybrids that showed variations on soluble solids of 8.58 to $10.04 \%$. According to Li et al. (2019) soluble solid is the most important parameter to access the melon quality by consumers or industry. Differences of soluble solids among studies about soluble solids are associated to variation of varieties, growth conditions and method to obtain maturation (Vallone et al., 2013). The non-commercial (Access 16 and 2) melons showed on the last day of evaluation, 4.6 and $3.8 \%$ of soluble solids, lower than the soluble solids found in commercial melons. This difference is consistent with the soluble solid of Momordica melon variety obtained by Aragao et al. (2013) that evaluated the genetic divergence of 38 melon accessions from traditional agriculture of the Brazilian Northeast and with Dhillon et al. (2007) that evaluated the diversity among landraces of Indian snap melon (Cucumis melo var. momordica). 

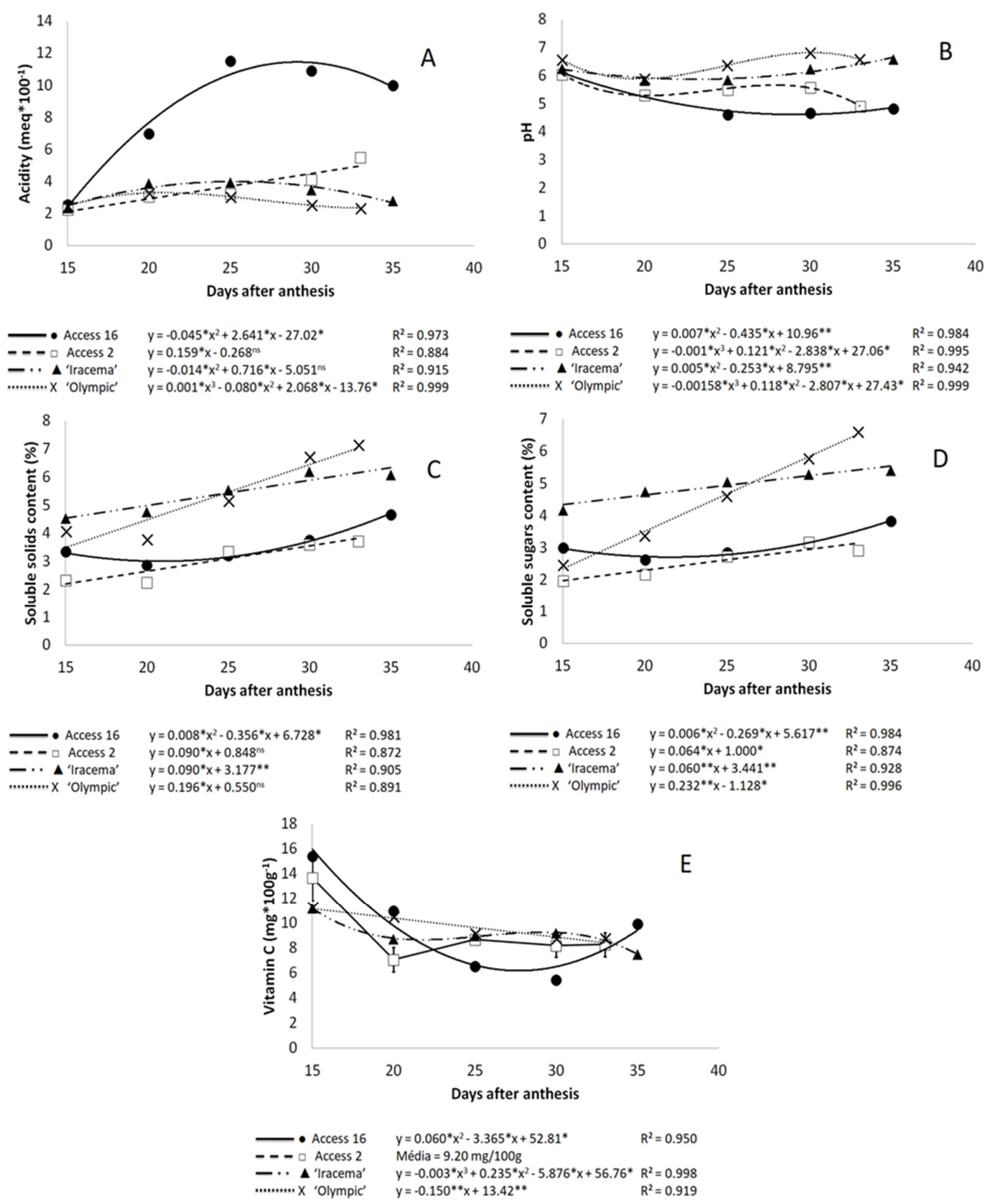

Figure 2. a) Titratable acidity, b) pH, c) soluble solids content, d) soluble sugar content and e) vitamin $\mathrm{C}$ of Acidulus (Access 16), Momordica (Access 2), Inodorus (cv. 'Iracema') e Cantalupensis (cv. 'Olympic') melons with different ripening degree at harvest. ${ }^{*}$ significant at $5 \%$ probability, ${ }^{* *}$ significant at $1 \%$ probability, ns= not significant

The concentration of soluble sugars of commercial and non-commercial melons had linear growth over the ripening time, as well as what happened to soluble solids (Figure $2 \mathrm{E}$ ). The commercial 'Olympic' melon showed sugar increment on soluble solids of $93.02 \%$ of sugars insoluble solids, which corresponded to an increase of $38.02 \%$, during ripening. The 'Iracema' melon showed $91.24 \%$ of sugar per soluble solids on the last day, even with a reduction in the concentration of $-3.04 \%$. Non-commercial melons (access 16 and 2) showed sugar per soluble solids concentration fell more intensely ( -5.06 and $-8.59 \%$ respectively), with 87.32 and 
$81.51 \%$ on the last day. The sugar concentration in melon during maturation can be attributed to stachyose and raffinose synthesis on the leaves, with posterior transport to the fruit, where it is converted to saccharose via enzymatic system (Dai et al., 2006). However, the fruit flavor is determined by a combination of sugars, organic acids, and volatile compounds and is affected by storage (Liu et al., 2019).

We observed a reduction in vitamin $\mathrm{C}$ content of commercial and non-commercial melons, during maturation, with estimated values around 7 to $10 \mathrm{mg}^{100 \mathrm{~g}^{-1}}$ of flesh at 35 days after anthesis. De Sousa et al. (2019) studied the induction of postharvest resistance of melon using pulsed light and found thar these melons decrease the vitamin $\mathrm{C}$ in $40.80 \%$ during storage. The relation of vitamin $\mathrm{C}$ loss with storage is related to the natural senescence process (Beaulieu, 2006). Here, the access 16 was the melon that showed the high loss during the ripening.

The ideal harvest time is possible to determine considering the studied variables, in view of the fruits having a climacteric or non-climacteric behavior. Here, the ideal harvest for 'Iracema' may be at 35 DAA, supported by soluble solids content and color data. The 'Olympic' melons, from Cantalupensisvariety, get ripe even after harvest. Data showed that 'Olympic' had a differenced development from 20 DAA, close to split, associated to organic acid consumption. Picking from this point can grant better physical resistance to handling and transportation, due to its higher firmness. On the other hand, early harvest can result in lower quality, after ripening since melon has low carbohydrate stock. Therefore, knowing the commercial destination is essential to determine the ideal harvest point, because if a long transportation time is required, the melon can be picked before 30 DAA, but otherwise, the ideal attributes for consumption will happen after that.

Fruits from non-commercial (access 16) showed highest acidity, with a peak on 29 DAA. Organic acid concentration normally does not represent a harvest determinant, which is because many study levels of organic acidy vary irregularly (Vallone et al., 2013). The point of the harvest of non-commercial access 2 is on 20 DAA, since the increase of soluble solids was not prominent, but its firmness loss was way too high, with fruit crack when ripe (vide cell wall metabolism). Access 2 has shown an increase in the acidity levels, until the maturation end, less prominent than access 16 . Ionica et al. (2015) studying the maturation of six melons cultivars verified, as well, different acidity comportments, but the highest concentration did not overcome $0,1 \%$.

Both accesses, as shown in results, have, unlike physical and chemical characteristics, ending an unusual

flavor. Melon is typically consumed as sweet table fruits, but Acidulus and Momordica varieties are good for cooking usage, being appreciated in Indian kitchen, as salads or food spice (Dhillon et al., 2007).

\section{Pulp firmness}

The melons lose the pulp firmness with ripening degree at harvest, that is, the melons collected in the last days after anthesis, showed less firmness of pulp. Among the commercial and non-commercial melons, the access 16 showed the highest pulp firmness values during the whole time (Figure 3). The pulp firmness loss of access 16 on the evaluated time was $30.83 \%$, while 'Iracema' had a reduction of $42.74 \%$. Besides the lower firmness loss, access 16 had high pulp firmness at the maturation end. Access 2 had pulp firmness loss of 67.38\%, while 'Olympic' had 71.73\%. Chisari et al. (2009) evaluating the comportment of 'Galia' and 'Piel de Sapo' melons during maturation verified pulp firmness loss of $29.19 \%$ and $70.77 \%$ respectively. Firmness values of present study corroborated also with Vallone et al. (2013). 


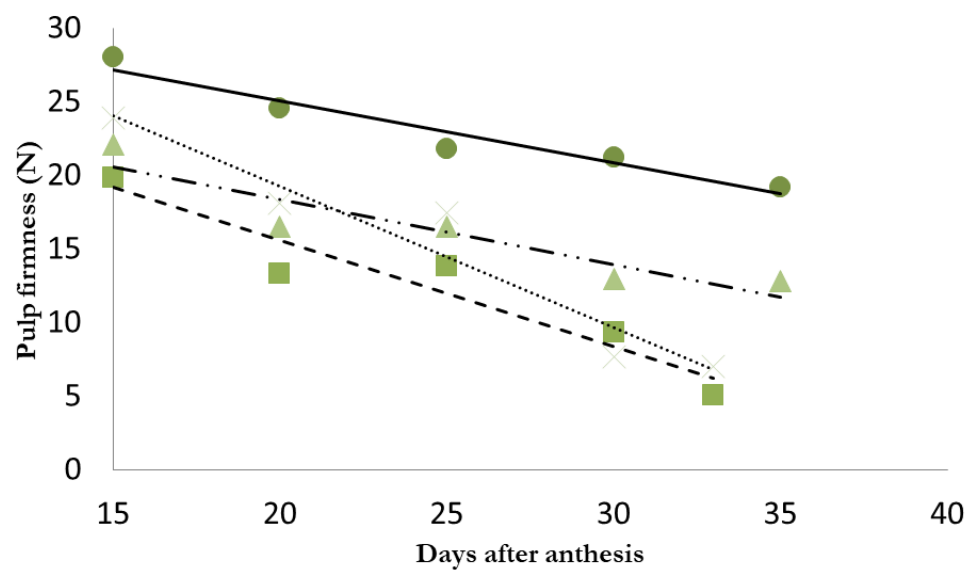

\begin{tabular}{|c|c|c|c|}
\hline & - Access 16 & $y=-0.419 * * x+33.46 * *$ & $R^{2}=0.939$ \\
\hline & $\square A$ & $y=-0.718^{*} x+29.95^{* *}$ & $R^{2}=0.906$ \\
\hline & $\boldsymbol{\Delta}$ 'Iracema' & $y=-0.440 * x+27.19 * *$ & $R^{2}=0.857$ \\
\hline ..." & X 'Olympic' & $y=-0.960 * * x+38.49 * *$ & $R^{2}=0.932$ \\
\hline
\end{tabular}

Figure 3. Pulp firmness of Acidulus (Access 16), Momordica (Access 2), Inodorus (cv. 'Iracema') e Cantalupensis (cv. 'Olympic') melons melons with different ripening degree at harvest. ${ }^{*}$ for significant at $5 \%$ probability, ${ }^{* *}$ for significant at $1 \%$ probability, ns for not significant

Pectin methylestarese (PME), polygalacturonase (PG), beta-galactosidase (Bel-agal) activities, Watersoluble pectin (WSP), chelate-soluble pectin (CSP) and sodium carbonate soluble pectin (SSP) content

The non-commercial (access 2 and 16) melons showed the higher pectin methylesterase enzyme (PME) activity and increased with the ripening degree at harvest, with maximum activities of 5671.60 and 3834.50 $\mathrm{UA}^{*} \mathrm{~g}$ of flesh ${ }^{-1 *} \mathrm{~min}^{-1}$ at 29 and 33 DAA respectively (Figure $4 \mathrm{~A}$ ). On the other hand, the commercial melons showed PME activity no higher than $1200 \mathrm{UA}^{*} \mathrm{~g}$ of pulp ${ }^{-1 *} \mathrm{~min}^{-1}$. These enzymes are belonging to family 8 carbohydrate esterase categorized under pectin esterase superfamily. Pectin methylesterase in plants has an important role in cell wall metabolism during fruit ripening (Rajulapati and Goyal, 2017) and can reduce pulp firmness in addition to it can maintain or even improve firmness. Through demethylation, turning regions of the uronic acid backbone into apt substrate for poligalacturonase (PG), as well as it can propitiate the association of calcium ions to the available linkage, slowing down PG access, and enabling yet crossed links between backbones, with possibly firmness increment (Silveira et al., 2011).

The commercial melons 'Iracema' and 'Olympic' had an expected behavior about relation among PG and PME, as PME action peak preceded the PG one (23 and 20 DAA for PME and 28 and 25 DAA for PG respectively (Figures $4 \mathrm{~A}$ and $\mathrm{B}$ ). The high $\mathrm{PG}$ action in each commercial melon is repressed due to the low PME activity, because PME action is necessary to PG hydrolytic activation and its substrate that cleaves the residue demethylated D-galacturonic acid from pectin backbone galacturonan (Belge et al., 2017).

The non-commercial melon (access 16) showed PG maximum activity preceded for one day the PME peak, at 29 DAA. The access 2 melon did not even have a peak for PME, before tissue rupture. On the other hand, access 2 has a higher PG action, due to its association with the growing PME activity, so this may be related to the tissue cracking for this access at the latter days observed. 

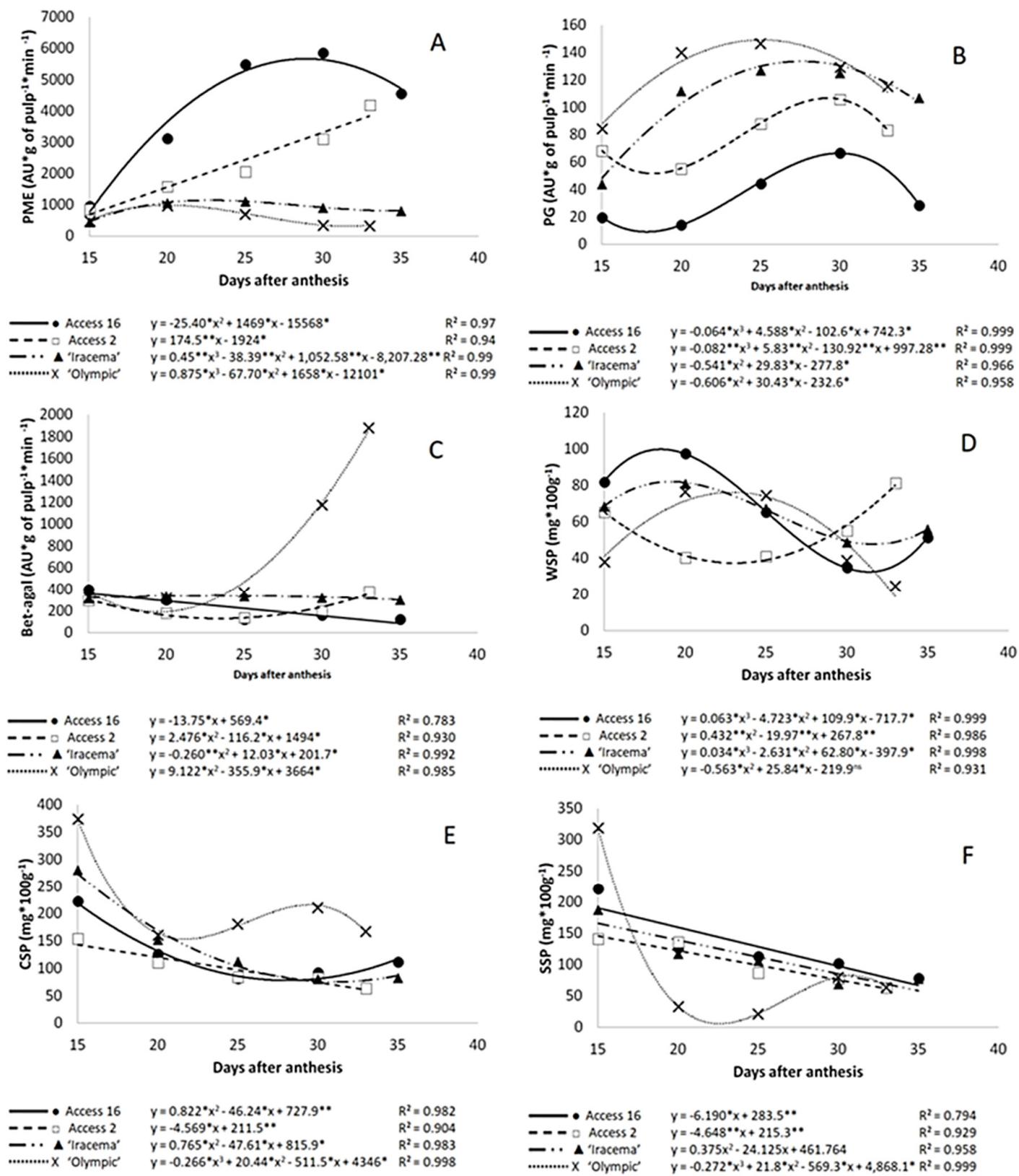

Figure 4. a) Pectin methylestarese (PME), b) polygalacturonase (PG), c) beta-galactosidase (Bel-agal) activities, d) water (WSP), e) chelate (CSP) and f) sodium carbonate soluble pectins (SSP) content of Acidulus (Access 16), Momordica (Access 2), Inodorus (cv. 'Iracema') e Cantalupensis (cv. 'Olympic') melons with different ripening degree at harvest. ${ }^{*}$ for significant at $5 \%$ probability, ${ }^{* *}$ for significant at $1 \%$ probability, ns for not significant

All treatments had high levels of PG activity (Figure $4 \mathrm{~B}$ ), reaching about $150 \mathrm{UA}^{*} \mathrm{~g}$ of pulp ${ }^{-1 *} \mathrm{~min}^{-1}$, especially compared with Supapvanich and Tucker (2013) that evaluated the cell wall hydrolyses of net melons, during storage, and got maximum activity of $5 \mathrm{UA}^{*} \mathrm{~g}$ of $\mathrm{pulp}^{-1 *} \mathrm{~min}^{-1}$.

The Beta-gal activity is responsible for cleave neutral sugar side chains from the pectic polymer and cell wall-related enzyme activities after fruit storage (Belge et al., 2016). Here, the commercial melon 'Olympic' had from $20 \mathrm{DAA}$ a sudden increase on Beta-gal activity, reaching $1800 \mathrm{UA}^{*} \mathrm{~g}$ of flesh ${ }^{-1 *} \mathrm{~min}^{-1}$ at last day (Figure 
$4 \mathrm{C})$, affecting considerably the pulp firmness loss, the highest loss rate among evaluated materials. The noncommercial Access 2 had similar elevation on its beta-gal activity, but less expressive as observed on 'Olympic', with growth starting from $23 \mathrm{DAA}$, coming to $355.76 \mathrm{UA}^{*} \mathrm{~g}$ of pulp ${ }^{-1 *} \mathrm{~min}^{-1}$ at last day. Either 'Iracema' or access 16 had an overall decrease of beta-gal activity, 15.47 and $68.15 \%$ respectively; the low beta-gal activity for access 16 is also associated to its high pulp firmness retention during maturation.

Beta-gal enzyme can even act on fruit sugar concentration system, during development. In melons, sugars are transferred mainly on stachyose form, during the phloem unload it is broken until sucrose form, or even to fructose or glucose. This process is carried out by an enzymatic complex, from the peduncle to the fruit, where beta-gal could act on cleavage of galactose present on stachyose. As higher is the fruit metabolic activity, stronger is the drain on phloem partition system (Taiz and Zeiger, 2010), so beta-gal could be considered an indicative of metabolic activity. According to the present study, there was increment of sugar on soluble solids only for 'Olympic', which expressed extremely high beta-gal activity, been possible to associate this enzyme activity not only to firmness, but also to sugar concentration.

Vallone et al. (2013) studding 'MasRico' and 'Navigator' melons, from reticulatus, verified that 'MasRico' had cucumber aroma, bitter taste, and higher texture, while 'Navigator' had opposite trend, with less firmness, and sweet flavour. Bianchi et al. (2016) studying melon texture did not verified correlation among soluble solids and fruit firmness.

Water-soluble pectin (WSP) of non-commercial access 16 and both commercial cultivars showed a growth peak followed by a decrease (Figure 4D). This fact occurred due to the elevated concentration of methylated pectin, synthesized on Golgi complex at maturation begin and then transferred to via vesicles to outer cell, where it is demethylated by pectin-esterases, building links between then, becoming less soluble with time (Taiz and Zeiger, 2010). Access 2 showed uronic acid accumulation until maturation end. According to Chong et al. (2015), long chain pectin fractions, less soluble in water, are the ones more correlated with firmness in melons, but, the concentration of soluble pectin's in access 2 is well associated with pulp firmness, and with the fruit cracks at maturations ending.

However, chelate soluble (CSP) and sodium carbonate soluble (SSP) are the pectin's that showed more relation with firmness. Here, CSP was more abundant in 'Olympic' melon (Figure $4 \mathrm{E}$ ), during the ripening, besides that this cultivar had a high pulp firmness loss. This result points to the significant importance of other cell wall elements, such as hemicellulose and cellulose, to study the firmness of Cantalupensis variety. Access 16 had the higher estimated CSP concentrations on last day compared to 'Iracema', 116.45 and $86.68 \mathrm{mg}^{*} 100 \mathrm{~g}^{-1}$ respectively, because, mainly, to the lower enzyme degradation observed to the access.

Sodium carbonate soluble pectin (SSP) was most concentrated in non-commercial access 16 fruits $\left(66.85 \mathrm{mg}^{*} 100 \mathrm{~g}^{-1}\right)$ at $35 \mathrm{DAA}$ (Figure $\left.4 \mathrm{~F}\right)$. This result highlights the relation among long chains pectin content and melon firmness, since the comportment of decrease on SSP is related to the pulp firmness loss. In the same way, the beta-gal had an inverse relation with firmness and SSP content. However, the pectin levels during maturation contributed to the cracking of access 2 melon. The possible causes of this may be an association between other factors as hemicellulose and cellulose degradation, rind thickness, and cell membrane degradation, promoting tissue collapse. The CSP and SSP showed relation with pulp firmness loss of the 'Iracema' melon.

\section{Conclusions}

This comparative study has pointed out the different precocity of non-commercial and commercial melons. The non-commercial access 2 showed more precocity because its better ripening degree at harvest had happened at 20 days after anthesis. The 30 days after anthesis is the best time to harvest the commercial 'Olympic' and non-commercial (access 16). The best harvest day for 'Iracema' was 35 days after anthesis. 
The high pulp firmness of access 16 is associated with high levels of chelate-soluble pectin and SSP, and low poligalacturonase and beta-galactosidase activities.

The tissue rupture of access 2 is related to the high pectinase activity, as well as the reduction of pectin content.

\section{Authors' Contributions}

Conceptualization: PLDM and GHSN; Data curation: FMP, JDAS and NJAM; Formal analysis: FMP, JDAS and NJAM; Funding acquisition: EVM and PLDM; Investigation: FMP, JDAS and NJAM; Methodology: PLDM, FMP, JDAS and NJAM; Project administration: PLDM; Resources: PLDM and EVM; Software: GHSN; Supervision: PLDM, EVM and GHSN; Validation: FMP, JDAS and NJAM; Visualization: FMP, JDAS and NJAM; Writing - original draft: PLDM and FMP; Writing - review and editing: EVM.

All authors read and approved the final manuscript.

\section{Acknowledgements}

This work was supported ed by the Coordenação de Aperfeiçoamento de Pessoal de Nível Superior Brazil (CAPES), grant number 0001.

\section{Conflict of Interests}

The authors declare that there are no conflicts of interest related to this article.

\section{References}

AOAC (2002). Official methods of analysis of the Association of Official Analytical Chemistry. AOAC (17th ed), Washington.

Aragao FAS, Torres J, Nunes GHS, Queiroz MA, Bordallo PN, Buso GSC, ... Neto FB (2013). Genetic divergence among accessions of melon from traditional agriculture of the Brazilian Northeast. Genetics and Molecular Research 12:6356-6371. https://doi.org/10.4238/2013.December.6.3

Araújo Neto SEd, Gurgel FdL, Pedrosa JF, Ferreira RLF, Araújo ADP (2003). Produtividade e qualidade de genótipos de melão-amarelo em quatro ambientes [Productivity and quality of genotypes of yellow melon in four environments]. Revista Brasileira de Fruticultura 25:104-107. https://doi.org/10.1590/S010029452003000100030

Beaulieu JC (2006). Volatile changes in cantaloupe during growth, maturation, and in stored fresh-cuts prepared from fruit harvested at various maturities. Journal of the American Society for Horticultural Science 131(1):127-139. https://doi.org/10.21273/JASHS.131.1.127

Belge B, Goulao LF, Comabella E, Graell J, Lara I (2017). Refrigerated storage and calcium dips of ripe 'Celeste'sweet cherry fruit: Combined effects on cell wall metabolism. Scientia Horticulturae 219:182-190. https://doi.org/10.1016/j.scienta.2017.02.039

Bianchi T, Guerrero L, Gratacos-Cubarsi M, Claret A, Argyris J, Garcia-Mas J, Hortos M (2016). Textural properties of different melon (Cucumis melo L.) fruit types: Sensory and physical-chemical evaluation. Scientia Horticulturae 201:46-56. https://doi.org/10.1016/j.scienta.2016.01.028

Chen HJ, Cao SF, Fang XJ, Mu HL, Yang HL, Wang X, ... Gao HY (2015). Changes in fruit firmness, cell wall composition and cell wall degrading enzymes in postharvest blueberries during storage. Scientia Horticulturae 188:44-48. https://doi.org/10.1016/j.scienta.2015.03.018 
Chisari M, Silveira AC, Barbagallo RN, Spagna G, Artes F (2009). Ripening stage influenced the expression of polyphenol oxidase, peroxidase, pectin methylesterase and polygalacturonase in two melon cultivars. International Journal of Food Science \& Technology 44:940-946. https://doi.org/10.1111/j.1365-2621.2008.01735.x

Chong JX, Lai SJ, Yang HS (2015). Chitosan combined with calcium chloride impacts fresh-cut honeydew melon by stabilising nanostructures of sodium-carbonate-soluble pectin. Food Control 53:195-205. https://doi.org/10.1016/j.foodcont.2014.12.035

Cohen S, Tzuri G, Harel-Beja R, Itkin M, Portnoy V, Sa'ar U, ... Rogachev I (2012). Co-mapping studies of QTLs for fruit acidity and candidate genes of organic acid metabolism and proton transport in sweet melon (Cucumis melo L.). Theoretical and Applied Genetics 125:343-353. https://doi.org/10.1007/s00122-012-1837-3

Dai N, Petreikov M, Portnoy V, Katzir N, Pharr DM, Schaffer AA (2006). Cloning and expression analysis of a UDPgalactose/glucose pyrophosphorylase from melon fruit provides evidence for the major metabolic pathway of galactose metabolism in raffinose oligosaccharide metabolizing plants. Plant Physiology 142:294-304. https://doi.org/10.1104/pp.106.083634

De Sousa AED, de Almeida Lopes MM, Moreira ADR, Macedo JJN, Moura CFH, de Aragão FAS, de Oliveira Silva E (2019). Induction of postharvest resistance in melon using pulsed light as abiotic stressor. Scientia Horticulturae 246: 921-927. https://doi.org/10.1016/j.scienta.2018.11.066

Dhillon NPS, Ranjana R, Singh K, Eduardo I, Monforte AJ, Pitrat M, ... Singh PP (2007). Diversity among landraces of Indian snapmelon (Cucumis melo var. momordica). Genetic Resources and Crop Evolution 54:1267-1283. https://doi.org/10.1007/s10722-006-9108-2

Esteras C, Rambla JL, Sánchez G, Granell A, Picó MB (2020). Melon genetic resources characterization for rind volatile profile. Agronomy 10(10):1512. https://doi.org/10.3390/agronomy10101512

Ionica ME, Nour V, Trandafir I (2015). Evolution of some physical and chemical characteristics during growth and development of muskmelon (Cucumis melo L.). Pakistan Journal of Agricultural Sciences 52:265-271.

Jen JJ, Robinson ML (1984). Pectolytic enzymes in sweet bell peppers (Capsicum annuum). Journal of Food Science 49:1085-1087. https://doi.org/10.1111/j.1365-2621.1984.tb10398.x

Kozioł A, Cybulska J, Pieczywek PM, Zdunek A (2017). Changes of pectin nanostructure and cell wall stiffness induced in vitro by pectinase. Carbohydrate Polymers 161:197-207. https://doi.org/10.1016/j.carbpol.2017.01.014

Li M, Han D, Liu W (2019). Non-destructive measurement of soluble solids content of three melon cultivars using portable visible/near infrared spectroscopy. Biosystems Engineering 188:31-39. https://doi.org/10.1016/j.biosystemseng.2019.10.003

Li X, Li C, Sun J, Jackson A (2020). Dynamic changes of enzymes involved in sugar and organic acid level modification $\begin{array}{lllll}\text { during blueberry fruit maturation. Food } & \text { Chemistry }\end{array}$ https://doi.org/10.1016/j.foodchem.2019.125617

Li XW, Cao SF, Zheng YH, Sun AP (2011). 1-MCP suppresses ethylene biosynthesis and delays softening of 'Hami' melon during storage at ambient temperature. Journal of the Science of Food and Agriculture 91:2684-2688. https://doi.org/10.1002/jsfa.4514

Liu B, Jiao W, Wang B, Shen J, Zhao H, Jiang W (2019). Near freezing point storage compared with conventional low temperature storage on apricot fruit flavor quality (volatile, sugar, organic acid) promotion during storage and related shelf life. Scientia Horticulturae 249:100-109. https://doi.org/10.1016/j.scienta.2019.01.048

Manohar SH, Murthy HN (2012). Estimation of phenotypic divergence in a collection of Cucumis melo, including shelflife of fruit. Scientia Horticulturae 148:74-82. https://doi.org/10.1016/j.scienta.2012.09.025

Miller GL (1959). Use of dinitrosalicylic acid reagent for determination of reducing sugars. Analytical Chemistry 31:426434. https://doi.org/10.1021/ac60147a030

Munira ZA, Rosnah S, Zaulia O, Russly AR (2013). Effect of postharvest storage of whole fruit on physico-chemical and microbial changes of fresh-cut cantaloupe (Cucumis melo L. reticulatus cv. Glamour). Food Research International 1:501-508.

Ortiz-Duarte G, Pérez-Cabrera LE, Artés-Hernández F, Martínez-Hernández GB (2019). Ag-chitosan nanocomposites in edible coatings affect the quality of fresh-cut melon. Postharvest Biology and Technology 147: 174-184. https://doi.org/10.1016/j.postharvbio.2018.09.021

Pressey R, Avants JK (1973). Two forms of polygalacturonase in tomatoes. Biochimica et Biophysica Acta 309:363-369. https://doi.org/10.1016/0005-2744(73)90035-1

Purquerio LFV, Cecílio Filho AB (2005). Nitrogen concentration in nutrient solution and number of fruits on quality of melon fruits. Horticultura Brasileira 23:831-836. https://doi.org/10.1590/S0102-05362005000300028 
Queiroga RCFD, Puiatti M, Fontes PCR, Cecon PR (2008). Produtividade e qualidade do melão Cantaloupe, cultivado em ambiente protegido, variando número e a posução dos frutos na planta. Bragantina 67:911-920. https://doi.org/10.1590/S0006-87052008000400013

Rajulapati V, Goyal A (2017). Molecular cloning, expression, and characterization of pectin methylesterase (CtPME) from Clostridium thermocellum. Molecular Biotechnology 59(4-5):128-140. https://doi.org/10.1007/s12033017-9997-7PMID: 28332030

Rizzo AA, Braz LT (2001). Características de cultivares de melão rendilhado cultivafas em casa de vegetação [Evaluation of qualitative characteristics of netted melon fruits under greenhouse conditions]. Horticultura Brasileira 19:370373. https://doi.org/10.1590/S0102-05362001000300017

Sales R, Nunes GHS, Silva KJP, Costa GG, Guimaraes IM, Michereff SJ (2015). Reaction of melon accessions to Rhizoctonia solani. Horticultura Brasileira 33:196-202. https://doi.org/10.1590/S0102-053620150000200010

Silveira AC, Aguayo E, Chisari M, Artes F (2011). Calcium salts and heat treatment for quality retention of fresh-cut 'Galia' melon. Postharvest Biology and Technology 62:77-84. https://doi.org/10.1016/j.postharvbio.2011.04.009

Strohecker R, Henining HM (1967). Análisis de vitaminas: métodos comprobrados. Madrid, Paz Montalvo.

Supapvanich S, Tucker GA (2013). The effect of 1-methylcyclopropene (1-MCP) on quality and cell wall hydrolases activities of fresh-cut muskmelon (Cucumis melo var reticulatus L.) during storage. Food Biotechnology 6:21962201. https://doi.org/10.1007/s11947-011-0776-3

Tadmor Y, Burger J, Yaakov I, Feder A, Libhaber SE, Portnoy V, Meir A, Tzuri G, Saar U, Rogachev I (2010). Genetics of flavonoid, carotenoid, and chlorophyll pigments in melon fruit rinds. Journal of Agricultural and Food Chemistry 58:10722-10728. https://doi.org/10.1021/jf1021797

Taiz L, Zeiger E (2010). Plant physiology. Sinauer Associates.

Tomaz HVD, Aroucha EMM, Nunes GHD, Neto FB, Queiroz RF (2009). Postharvest quality of different yellow melon hybrids stored under refrigeration. Revista Brasileira de Fruticultura 31:987-994. https://doi.org/10.1590/S010029452009000400011

Vallone S, Sivertsen H, Anthon GE, Barrett DM, Mitcham EJ, Ebeler SE, Zakharov F (2013). An integrated approach for flavour quality evaluation in muskmelon (Cucumis melo L. reticulatus group) during ripening. Food Chemistry 139:171-183. https://doi.org/10.1016/j.foodchem.2012.12.042

Zhang H, Wang HS, Yi HP, Zhai WQ, Wang GZ, Fu QS (2016). Transcriptome profiling of Cucumis melo fruit development and ripening. Horticulture Research 3:10. https://doi.org/10.1038/hortres.2016.14
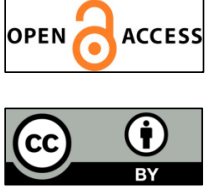

The journal offers free, immediate, and unrestricted access to peer-reviewed research and scholarly work. Users are allowed to read, download, copy, distribute, print, search, or link to the full texts of the articles, or use them for any other lawful purpose, without asking prior permission from the publisher or the author.

License - Articles published in Notulae Botanicae Horti Agrobotanici Cluj-Napoca are Open-Access, distributed under the terms and conditions of the Creative Commons Attribution (CC BY 4.0) License. (c) Articles by the authors; USAVM, Cluj-Napoca, Romania. The journal allows the author(s) to hold the copyright/to retain publishing rights without restriction. 